\title{
Environmental Policy Regulation and Law - Biodiversity in Healthcare
}

\section{Harold Kovach}

Forensic Anthropologist, MS Criminal Justice, JD Owner \& EO, 409 Canary Lane, Statesboro, USA

*Corresponding author: Dr. Harold L Kovach, Ph.D, Forensic Anthropologist, MS, Criminal Justice, JD Owner \& EO, 409 Canary Lane, Statesboro, GA. 30461, Tel: (912) 587-2016; E-mail: iccr.forensics@gmail.com

Rec date: July 15, 2015 Acc date: August 21, 2015 Pub date: August 27, 2015

Copyright: $\odot 2015$ Kovach $\mathrm{H}$. This is an open-access article distributed under the terms of the Creative Commons Attribution License, which permits unrestricted use, distribution, and reproduction in any medium, provided the original author and source are credited.

\begin{abstract}
In this Paper, I will discuss the nature of healthcare and biodiversity as it pertains to everyday life. I will discuss DNA barcoding as a complementary tool for conservation and valorization of forest resources. We will look at Medical tree species in a plantation of Bangladesh, as well as the medicinal values, increment density and frequency of these species in Bangladesh. This paper is a global look at the biodiversity in healthcare V. pharmaceuticals, and DNA barcoding. The "core barcode" for land plants was tested on 68 tree specimens. Since the pre-historic era, humans have been using forest as food, drugs, and handcraft reservoir. Today, the use of botanical raw material to produce pharmaceuticals, herbal remedies, teas, spirits, cosmetics, sweets, dietary supplements, special industrial compounds and crude materials constitute an important global resource in terms of healthcare and economy. In recent years, DNA barcoding has been suggested as a useful molecular technique to complement traditional taxonomic expertise for fast species identification and biodiversity inventories. In this paper, application of DNA barcodes will be discussed as well as assessments of the biodiversity in healthcare.
\end{abstract}

Keywords: Biodiversity; Environmental policy regulation; Healthy ecosystems

\section{Introduction}

Empirical evidence will show how plants, trees, and species played a large role in ancient medical traditions and how we actually still practice them at home today, and play a vital role in providing healthcare as western medicines do. Many examples suggest that exploring traditional pharmacopoeia is a productive way to again identify leads, such as Physostigma venenosum, Strophantus spp. Camptotheca acuminate, Huperzia serrate, Carapichea ipecacuanha and Artemisia annua. As the demand for botanical products is increasing and most of the new products are harvested from the wild, questions of biodiversity and sustainability become very important. Here are three examples of prominent medicinal plants; (Taxus brevifolia, Rauvvolfia spp, and Prunus africana), reveal both the difficulties involved, and the biological and social implications, of drug recovery. Further studies of preserving biodiversity as possible solutions to these problems are also implemented in the community health as well.

\section{Discussion}

Healthy ecosystems and biological diversity (biodiversity) are sources of various goods and services that nurture life on earth and enhance human well-being. While the relevance of biodiversity to modern health care delivery may be clear, as seen in the commercial use of biological resources for pharmaceuticals, the relevance of biodiversity in the healthcare of people in economically disadvantaged and/or relatively isolated regions of the world can be considered to be fundamentally connected to their very survival. These regions may be rich in a variety of resources, (such as medicinal and nutritional and related knowledge), and have naturally abundant biodiversity, but they often lack sufficient public health care infrastructure as well as adequate personnel. According to the World Health Organization (WHO), "Health is both a resource for, as well as an outcome of, sustainable development cannot be achieved when there is a high prevalence of debilitating illness and poverty, and the health of a population cannot be maintained without a responsive health system and a healthy environment; environmental degradation, mismanagement of natural resources, and unhealthy consumption patterns and lifestyles impact health. Ill-health, in turn, hampers poverty alleviation and economic development" (WHO, 2002).

Forest figure prominently among the world's most important ecosystems. The importance of trees and sustaining biodiversity and all habitat stability, as well as to provide a large variety of environmental services is well acknowledged. Nevertheless, the increasing human impact, the recent environmental decay, and the ongoing climate change are among the main factors affecting forest communities, which in turn can affect our needs for certain plant life for medicinal sustainability, especially at local and regional scales within the Mediterranean basin (Forest Europe, (UNECE and FAO 2011). In the meantime, international market pressures call for higher quality standards. One way to convince decision-makers of the importance of conserving wild plants and habitats is to demonstrate their medical and economic growth and potential [1]. The socioeconomic contribution of wildlife and forest to livelihood and the impact of their use on the environment are the essential components of modern concepts for sustainable forest management [2].

Temperate and boreal forest are a traditional source, not only for timber but for many products that have been extracted from forest for millennia, including resin, tannin, fodder, litter, medical plants, fruits, nuts, roots, mushrooms, seeds, honey, ornamentals and exudates. Today there is an institutional rediscovery of the value of forest products and biodiversity for health products and services other than timber, and the total value of Non-Wood Goods (NWGs), reported in Europe has almost tripled since 2007 (FOREST EUROPE, UNECE and FAO 2011) [3]. 
Beside wood trade, Mediterranean woody flora includes numerous valuable species use of ornamentals or for secondary products processing and marketing (edibles, industrial and medicinal compounds). The option of stimulating the production of non-timber forest products has long been considered promising [2], and it is well illustrated in the case of Medicinal and Aromatic Plants, (MAPs). In many Euro-Mediterranean countries, (MAPs) resources are still unknown or overlooked. In other countries (MAPs) and the necessary plant materials (NPMs), roots, bark, leaves, fruits and seeds" are generally collected and sold by local people to traders and to the industry. Final products are then purchased by international exporters (WHO 2003). Forest overexploitation, product forgery and misidentifications are common risk, with the latter two usually occurring as a result of morphologically indistinguishable materials, species with similar common names, or intentional substitution of economically valuable materials by inexpensive specimens. At the same time, plant misidentification and forgery are serious threats to human health $[3,4]$.

The Identification of herbal medicinal materials using traditional, organoleptic and chemical methods can be very difficult, particularly for processed materials of a plant. Also plant germplasm (seeds and seedlings purchased for the establishment of (MAPs) orchards, afforestation programs, and ornamentals, may be difficult to recognize. Therefore, an accurate, universal, stable and specific method in Bangladesh allowing non-specialist ti identify the source species from a tiny amount of tissue is needed. Molecular Technology is considered a reliable alternative tool for identification of plant species and DNA barcoding is the latest move towards the generation of universal standards. A DNA barcode is a universally accepted short DNA sequence allowing the prompt and unambiguous identification of species, promoted for a variety of biological applications, including biodiversity inventories, the identification of medical plants, of natural health products, and of tree species listed in the Convention on International Trade of Endangered Species [3,4].

Based on the relative ease of amplification, sequencing, multialignment and the amount of variation displayed (sufficient to discriminate among sister species without affecting their correct assignation through intraspecific variation), three plastid loci are currently used in plants: rbcL, (a universal but slowly evolving coding region), matK (a relatively fast evolving coding region) and trnH-psbA (a rapidly evolving intergenic spacer) CBOL Plant Working Group 2009). More recently, the nuclear ribosomal internal transcribed spacer (ITS) has also been suggested as an efficient barcoding locus for complex plant groups in Europe, Bangladesh, and the United States.

Tree taxa have peculiar biological, evolutionary and taxonomic features that are likely to constitute a challenge to species recognition through DNA barcodes, viz. the generally low mutation rate of the plastid DNA, their ability to hybridize, and their narrowly defined species limits. Nevertheless, DNA barcoding has proven its utility in several detailed studies of tree genera. In this study, the application of DNA barcoding was applied to a number of indigenous and introduced tree species in the Mediterranean, and Bangladesh area, with medicinal, ornamental, edible, industrial and conservation relevance. Taxa were analyzed with the core barcode for land plants (rbcL, matK, and trnH-psbA); ease and success to achieve correct species identification were evaluated based on the relative efficiency of each marker, data quality and representation in the GenBank/EMBL database. The main objective is to provide a contribution to the future assemblage of a regional data/species inventory in the Bangladesh and
Mediterranean area for adequate identification, conservation and trade control of these valuable resources [4-8].

\section{Bangladesh and Medicinal Values}

Bangladesh is a tropical country and reasonably rich in biodiversity. A large number of herbs, shrubs and trees having medicinal values grow both in forests and in the home gardens. These are used as therapeutics either as first aid or total cure of an ailment. About 500 medicinal plant species have reported to occur in Bangladesh and $80 \%$ of rural populations depend on them for their primary health care. There are about 422 herbal companies that export raw materials. A survey conducted by Bangladesh Forest Research Industries (BFRI), in 1980 and 1992 revealed that the medicinal industries in Bangladesh consume about $66 \%$ of raw materials from local supplies. Medicinal plants play a central role both in traditional medicines and for trade $[9,10]$.

Many scientific studies were conducted throughout the world on the diversity and status of medicinal plants.

\section{Uses and Potentials}

Local people identified the medicinal value of the (10) species against all types of diseases consistent with earlier uses recorded by Trupe (1986), Chaudhuri (1993) and Rashid (2000). However, the medicinal species are declining in species population due mainly to over-exploitation used for food, fuel, wood, fodder etc.

The species frequency and density: Frequency of occurrence of a particular species in an area denotes one of its biodiversity at that area. As I find, the first three highest frequencies was found are Aphanamixis polystacha, Acacia catechu, Syzgium grande, while another one I found was, Terminalia balerica, Mangifera indica, Artocarpus lacucha, as commonly found tree species among (16) wild species in the same area. From what I have researched, it can be said that the collection of data and the species known to help people on all walks of life can be found in the rain forest of Bangladesh.

\section{Conclusion}

Recently, an outstanding research interest towards DNA barcoding of regional floras as well as global floras with biological and or economical relevance has spread. In all present work, we lay the foundations towards DNA barcoding applications of important woody plant genera in the Mediterranean basin, such as Cedrus, Aesculus, Aesculus, Ilex, Passiflora, Punica, sambucus, Sorbus, Zizphus. All these genera include valuable taxa for multiple natural and economic purposes, and combine with similar DNA barcoding investigations performed on Euro-Mediterranean forested land in recent years. Gathered results exposed limitations of DNA barcoding, most of which are due to (1). The imperfect discrimination ability of the markers and methods currently in use (2); The biological peculiarities of some genera, and (3); The low taxonomic coverage of the reference databases. Future technological advances, additional markers and larger sample sets at different geographical scales (from continental to local) are therefore auspicated to improve current protocols and identification success for the practical conservation, biodiversity in plants, ecosystems and valorization of all forest natural resources [9-11]. 
Citation: Kovach H (2015) Environmental Policy Regulation and Law - Biodiversity in Healthcare. J Forensic Res 6: 307. doi: 10.4172/2157-7145.1000307

Page 3 of 3

\section{Bangladesh (Conclusion)}

This study was carried out through plantations of Chittagong University campus established from 1983 to 1998. The study for Bangladesh was conducted in an area that lies in between latitudes 22 degrees 47 degrees 45 degrees North and 22 degrees 29 "0" degrees and longitudes 91 degrees 46 degrees 30 degrees East 91 degrees 47 degrees and 45 degrees East covering about 1,271 acres of land, soils covering more than $60 \%$ of the area with coarse to moderately fine textured material, the rest with coarse to fine textured, alluvial and colluvial piedmont sediments. The surveyed area enjoys a tropical monsoon climate, characterized by hot, humid summer, and cool, dry winter. The actual rainy season (May to October) receives about 90 percent of the total precipitation. Mean annual rainfall ranges from $12 \mathrm{~mm}$ to 299 $\mathrm{mm}$ along with a range of mean annual temperature from 15.2 degrees C to 30.8 degrees C The study area covers a total of 86.77 hectares and study method of Rea and Parker (1997) was followed [11].

\section{References}

1. Kathe W (2006) Revision of the Guidelines on the Conservation of Medicinal Plants by WHO, IUCN, WWF, and TRAFFICR. In: Bolgers J, Craker LE, Lange D (eds) Medicinal and Aromatic Plants. Springer, The Netherlands, pp. 109-120.

2. Arnold JEM, Ruiz Perez M (2001) Can nontimber forest products match tropical forest conservation and development objectives? Ecological Economics 39: 437-447.
3. Unnikrishnan PM, Suneetha MS (2012) United Nations UniversityInstitute of Advanced Studies (UNU-IAS), Biodiversity and Community Health: connecting and linking nature, knowledge and practices on the ground.

4. Laiou A, Mandolini LA, Piredda R, Bellarosa R, Simeone MC (2013) DNA barcoding as a complementary tool for conservation and valorisation of forest resources. Zookeys: 197-213.

5. Rashid AZMM, Khatun M (1999) Medicinal Plants a Potential agroforestry component in Bangladesh, Agroforest. Today 9-10.

6. Kahn MS, Ali MA (2001) Medicinal Plants. 362-371, in Agriculture Research in Bangladesh in the 20th Century.

7. Sanou H, Kambou SH, Teklehaimanot Z, Dembele M, Yossi H, et al. (2004) Vegetative Propagation of Vitellaria Paradoxa by grafting. Agroforest. Syst. 60: 93-99.

8. Razi ASA (1988) Medicinal Plants of Bangladesh; Review paper. Institute of Forestry and Environmental sciences, University of Chittagong, Chittagong, Bangladesh 99.

9. Global Strategy for Plant Conservation (2002); Convention on Biological Diversity: Global Strategy for Plant Conservation, Montreal.

10. Heubl G (2010) New aspects of DNA-based authentication of Chinese medicinal plants by molecular biological techniques. Planta Med 76: 1963-1974.

11. Savolainen V, Cowan RS, Vogler AP, Roderick GK, Lane R (2005) Towards writing the encyclopedia of life: an introduction to DNA barcoding. Philos Trans R Soc Lond B Biol Sci 360: 1805-1811. 